\title{
Migrant Workers' Remittances and External Trade Balance in Sub-Sahara African Countries
}

\author{
Henry Okodua $^{1}$ \& Wumi Kolawole Olayiwola ${ }^{1}$ \\ ${ }^{1}$ Department of Economics, Covenant University, Ota, Ogun State, Nigeria \\ Correspondence: Henry Okodua, Department of Economics, Covenant University, Ota, Ogun State, Nigeria. \\ E-mail: okodua@gmail.com
}

Received: November 28, 2012

Accepted: December 31, $2012 \quad$ Online Published: February 22, 2013

doi:10.5539/ijef.v5n3p134

URL: http://dx.doi.org/10.5539/ijef.v5n3p134

\begin{abstract}
Workers' remittances represent a major source of private external finance for many developing countries. Moreover, these flows which have been on the upward trend in recent times are now widely regarded as important financial flows to many developing countries that receive them in large quantity. One major concern about remittances is that in countries receiving significant flows, the local currencies could appreciate artificially due to over-valuation; this might in turn be harmful to the overall trade balance and long-run economic growth of the receiving economies. This study investigates the possibility of this phenomenon in some selected Sub-Saharan African countries. The hypothesized link between workers' remittances and external trade balance was specified in a linear dynamic panel data model and estimated using the system Generalized Method of Moments.A major finding shows that remittance inflows have a contemporaneous negative but statistically insignificant impact on external trade balance across the sampled countries. This result suggests that remittance flows may not be helpful in promoting the goal of maintaining a sustainable external trade balance in the selected SSA economies.
\end{abstract}

Keywords: remittances, trade balance, sub-saharanafrica, dynamic panel data model, system generalized method of moments

\section{Introduction}

Workers' remittances flow unarguably has been on the upward trend in recent times and these flows represent a major source of private external finance for many developing countries. Lartey, Mandelman and Acosta (2010) believe that remittances are becoming increasingly important as a source of foreign income in terms of both magnitude and growth rate, exceeding the inflow of foreign aid and private capital in many countries. Remittances currently represent about one-third of total financial flows to the developing world. Remittances also double as the main transmitter of migration's development benefits to migrants sending economies. The literature on remittances is largely conclusive on the stable nature of these flows and their potential to significantly contribute to the poverty reduction process by enhancing the living standards of the beneficiaries. However, there is still a running debate on the possibility of the unpleasant experiences of a real exchange rate appreciation and a loss of competitiveness in the tradable sector of many small developing economies that receive significant inflows.

Official data on remittances inflow to Sub-Saharan Africa (SSA) reveal that the flow of remittances to the region has been far more stable than official aid flows and foreign direct investment (FDI). Besides, remittances flow is so resilient that they do not significantly decline even in conditions of instability and poor governance. Hence, remittance flows represent one of the least volatile sources of foreign exchange earnings. Workers' remittances flow has steadily increased since the mid 1980s. Officially recorded remittances were an estimated US\$206 billion in 2006, compared to US\$19.6 billion in 1985 (World Development Indicators, 2006). Remittances have been the second most important source of external finance for developing countries, being twice the size of Official Development Aid (ODA) and almost as large as FDI. World Bank (2009) reports that recorded remittances to developing countries in 2008 were estimated to have reached US\$305 billion. This is equivalent to nearly two percent of aggregate developing country gross domestic product (GDP) and well over half of estimated FDI inflows (US\$490 billion). The 2008 estimated remittances to developing countries are over twice as large as ODA of US\$119 billion received by developing countries. 
The importance of remittances for some countries in the SSA region can be best illustrated by expressing them as a ratio to GDP, while in others, the absolute total of per-capita value of remittances flows are more revealing. When considered as a share of GDP, workers' remittances can in fact be conveniently regarded as a vital source of finance for many developing countries. These flows contribute to the poverty reduction process by enhancing the living standards of the beneficiaries.Workers' remittances can also contribute to the poverty reduction process through the multiplier effects of flows which create additional demand, employment and income. Page and Adams (2003) found that a $10 \%$ increase of remittances per capita leads to a decline of the poverty head count by $3.5 \%$, due to multiplier effects on GDP growth.

Two major forces are expected to ensure the growth and sustenance of remittance flows: Globalization and the aging populations (Olayiwola et al., 2008). Globalization and the aging of developed economy populations will ensure that demand for migrant workers remains robust for years to come. Consequently, the volume of remittances will most likely continue to grow, since migrants will continue to support the elderly and other dependants in their countries of origin. However, challenges remain in determining how best to channel the flow of remittances through formal financial institutions to promote economic growth and development in sending countries (Chami et al. 2008).

The impact of remittances on the real exchange rate and export competitiveness, and the Dutch disease effect, is one important area of the debate. In countries receiving significant remittances flow, the local currencies could appreciate, which might be harmful to their long-run economic growth. Remittances may exhibit the Dutch disease effects on the competitiveness of the tradable sector of receiving economies if these flows cause an over-valuation of the local currencies. Chami et al. (2003) noted that remittances inflow may be large in some countries when compared to the size of the economy and supply constraints may also pose a significant hindrance to the expansion of the non-tradable sector. In addition, a significant portion of remittances receipt may actually be spent on domestic goods; in such cases, the Dutch disease phenomenon arises and policymakers will need to be mindful of this possibility. Moreover, significant remittances receipts may reduce the labour supply or labour market participation of recipients in which case remittances could lead adverse economic developmental outcomes in the SSA region.

As a consequence, remittances flow via the over-valuation of local currencies of receiving economies may cause a deterioration of the external trade. Since remittances increase purchasing power in general within the receiving economy, they also promote domestic demand and preferences here may actually be in favour of imported goods and services. This fact often results in the deterioration of the external trade balance of remittance receiving economies and could bring about a worsening of the overall balance of payments (BOP) position of these economies. The big question at this point is; to what extent does workers' remittance inflows impact on foreign trade balance in SSA countries? This study empirically examines this question by investigating and characterizing the relationship between trade balance and remittance flows in some selected remittance receiving SSAcountries.

The remainder of the paper is divided into sections as follows: section two deals with literature review while section three is concerned with data and methodology and it comprises the empirical model, definition of variables, data sources, and model estimation technique. Section four deals with empirical results and discussions and policy implications of findings. Section five provides some general concluding remarks.

\section{Literature Review}

The impact of remittances on the real exchange rate and export competitiveness, and the Dutch disease effect, represent an area with inconclusive debate within the remittance literature. In the case of countries that receive significant remittances, the supply surge in foreign currencies could constitute pressure on the local currencies, which as a natural response could appreciate. And this might be very harmful to the long-run economic growth objective of the receiving economy (a Dutch disease effect). Remittances inflow may be so significant in volume as to result in an artificial appreciation of the real exchange rate of the receiving economy. In this case, remittances inflow may reduce the foreign trade competitiveness which in turn, weakens the real external balance and by implication, the current account balance position of the recipient economy. Consequently, remittances in this context halt the receiving country's trade balance via a reduction in exports of traded goods. Overall, the occurrence of remittance receipts in volumes that reduce the foreign trade competitiveness of the receiving economy, will adversely impact on the trade balance as well as the economic development of the receiving economy.

The above concerns that massive inflow of remittances to small developing economies could generate a resource allocation from the tradable to the non-tradable sector have been raised in a number of studies (see: McCormick and Wahba, 2000; Amuedo-Dorantes and Pozo, 2004; Lopez et al., 2007; Acosta et al., 2009; etc.). Rodrik (2008) 
provides evidence that real exchange rate overvaluation undermines long-term economic growth, particularly for developing countries, andin those countries tradable goods production suffers disproportionately from weak institutions and market failures. This underscores the importance of the implications of remittances for real exchange rate movements.Acosta et al. (2009) find that in addition to the usual nominal exchange rate channel, remittances result in a shrinkage of, and resource re-allocations away from, the tradable sector through (i) increasing prices in the non-tradable sector, and (ii) reducing the labour supply to, and thereby increasing the production costs of, the otherwise labour-intensive non-tradable sector. Studies in Latin America (Amuedo-Dorantes and Pozo, 2004) and Cape Verde (Bourdet and Falck, 2006) provide additional evidences in support of a Dutch disease effect of remittances on the competitiveness of the tradable sector of the receiving economies.

Chami, et al. (2003), argue that in countries where remittances inflows are large compared to the size of the economy, where supply constraints are a significant hindrance to the expansion of the non-tradables sector, and where a significant portion of remittances are spent on domestic goods, policymakers will need to be alert to the possibility of a Dutch disease phenomenon. Moreover, remittances may reduce the labour supply or labour market participation of recipients. If these negative factors dominate, remittances could be detrimental to economic development in SSA.

López et al. (2008) provide a very useful discussion on the channel through which remittances, real exchange rate, and Dutch disease may be linked. According to them, workers' remittances can be viewed as a capital inflow, and a surge in inflows resulting from a positive remittances income shocks produce some extra spending on both tradables and non-tradables. However, there will be a relative price change between tradables and non-tradables in favour of non-tradables and this makes production of the latter more profitable. Consequently, the price shift and resulting resource re-allocation erodes the competitiveness of export-oriented sectors and at the same time, hurt import-competing sectors. The final result of this real exchange rate appreciation is normally increased import flows and lower export sales.

On the positive side however, some studies have evidences that sizeable remittances inflows do not always depress the external trade balance of the receiving economy. Bouhga-Hagbe (2004) found that in the case of Morocco, remittances receipts almost covered the trade deficit and actually explains the observed surpluses of the external current account, and the overall BOP.Meanwhile, the BOP surpluses have in turn contributed to the improvement of Morocco's external position as evidenced in the accumulation of foreign exchange reserves, which now cover the external public debt.Rajan and Subramanian (2005) believe that remittances may in fact be self-correcting as an overvalued currency deters remittances, and hence Dutch disease effects are not sustained.

This study contributes to the literature by extending the debate to the effect of remittance flows on external trade via real exchange rate appreciation within the SSA context. The study also contributes by accounting for the possibility of dynamic endogeneity in the hypothesized relationship and this has the overall effect of ensuring that the quality of results obtained in the study are much more reliable.

\section{Data and Methodology}

The impact of remittance flows on external trade balance using a linear dynamic panel data model is empirically analysed in this study.Specifically, this study evaluates whether remittance flows significantly impact on external trade balance in recipient economies. The underlying assumption here is that remittances may be positively correlated with real exchange rate appreciation in the recipient economy and thereby hindering the external foreign trade competitiveness of the recipient economy. Significant inflows of remittances may result in the artificial appreciation of the real exchange rate of the receiving economy and consequently penalize the traded goods sector (since its exportables now become more expensive and less competitive) in the other economies.

\subsection{The Empirical Model}

In modeling the impact of workers' remittances on external trade balance of the receiving economies of SSA, the work of Obstfeld and Rogoff (1996) is considered a major motivation because they argue that a positive transfer of resources to a country hurts its competitiveness in world markets by reducing the range of goods it exports. The reduction in competitiveness takes place because the transfer reduces the country's real exchange rate. The specified empirical model is made up of a dynamic panel model. This equation is an attempt to verify empirically whether remittances inflow brings about a significant variation in the external trade balance of the receiving economies.

$$
E T B=f\left(E T B_{t-1}, W R, R E E R, G D P g r, I N F, O P E N\right)
$$


The explicit form of the equation (1) is provided below:

$$
\begin{gathered}
E T B_{i t}=\lambda_{11 i}+\lambda_{12 i} E_{T B} B_{t-1}+\lambda_{13 i} W R_{i t}+\lambda_{14 i} R E E R_{i t}+\lambda_{15 i} \text { GDPgr }_{i t}+\lambda_{16 i} I N F_{i t}+\lambda_{17 i} \text { OPEN }_{i t}+\varepsilon_{1 i t} \\
i=1,2,3, \ldots, 30 \text { (countries) } t=1,2,3, \ldots, 10 \text { (years) }
\end{gathered}
$$

These variables are expected on a priori grounds to be signed as follows:

$$
\lambda_{11}, \lambda_{12}, \lambda_{14}, \lambda_{15}, \lambda_{16}, \lambda_{17}>0 \text { and } \lambda_{13}, \lambda_{16}<0
$$

Without any loss of generality, equations (2) may now be re-written in matrix notations to obtain the following linear dynamic panel data model:

$$
E T B_{i t}=\beta_{1} E T B_{i . t-1}+\beta_{2}^{\prime} X_{i t}+\beta_{3}^{\prime} W_{i t}+v_{i}+e_{i t}
$$

$X_{i t}$ is a vector of strictly exogenous covariates (ones dependent on neither current nor past $e_{i t}$ ); and may be written as:

$$
X_{i t}^{\prime}=(G D P g r, O P E N, I N F)^{\prime}
$$

$W_{i t}$ is a vector of predetermined covariates (which may include the lag of ETB) and endogenous covariates, all of which may be correlated with the $v_{i}$. These include:

$$
W_{i t}^{\prime}=\left(E T B_{t-1}, R E E R, W R\right)^{\prime}
$$

$\beta_{i}$ are vectors of parameters to be estimated.

$v_{i}+e_{i t}$ is the usual error component decomposition of the error term;

$v_{i}$ are unobserved individual-specific effects;

$e_{i t}$ are the observation-specific (idiosyncratic) errors;

$X_{i t}$ comprises variables that are defined as follows:

GDPgr $=$ growth rate of Gross Domestic Product (GDP)

OPEN = degree of trade openness

$$
I N F=\text { Inflation rate }
$$

$W_{i t}$ on the other hand comprises variables that are defined as follows:

$E T B_{t-1}=$ one period lag of the dependent variable, externaltradebalance

$R E E R=$ real effective exchange rate

$W R=$ worker's remittances receipt

Equation (3) may be rewritten in first differenced notations in order to get a consistent estimate of $\beta$ as $\mathrm{N} \rightarrow \infty$ with $\mathrm{T}$ fixed as follows:

$$
D \cdot E T B_{i t}=\beta_{1} D \cdot E T B_{i . t-1}+\beta_{2}^{\prime} D \cdot X_{i t}+\beta_{3}^{\prime} \text { D. } W_{i t}+D \cdot e_{i t}
$$

The unobserved individual-level effects, $v_{i}$ has been eliminated from the differenced equation (4) because it does not vary over time. The Ds are the first difference operators.

\subsection{Definition of Variables and Data Sources}

Data for all variables in this study were sourced from the World Bank, Africa development indicators and the International Monetary Fund (IMF), World Economic Outlook $(2005,2012)$. The study employs data on the variables and covering a period of ten years (2002-2011). The choice of this period is explained by the availability of data across the selected countries as well as the fact of a dramatic rise in recorded remittance flows to the region over this period. The definition of variables employed in the study and data sources are presented in the Table 1. 
Table 1. Definition of variables

\begin{tabular}{ll}
\hline Variable & Definition \\
\hline Workers' remittances (WR) & $\begin{array}{l}\text { Workers' remittances received comprise of current transfers by migrant workers. It is } \\
\text { measured as a ratio of GDP }\end{array}$ \\
This is the annual percentage change in consumer price index (CPI) \\
$\begin{array}{l}\text { Growth rate of Gross Domestic Product (GDPgr) } \\
\text { Trade Openness(OPEN) }\end{array}$ & $\begin{array}{l}\text { This is the annual percentage change in the value of the real GDP } \\
\text { Degree of trade openness measured by the volume of trade (export plus imports) } \\
\text { divided by the GDP for a given year. }\end{array}$ \\
External Trade Balance (ETB) & $\begin{array}{l}\text { ETB is the difference between the monetary value of exports and imports of output in } \\
\text { an economy over a given year }\end{array}$ \\
Real Effective Exchange Rate (REER) & $\begin{array}{l}\text { This is the nominal exchange rate that has accounted for the inflation differentials in } \\
\text { each country over time. }\end{array}$ \\
\hline
\end{tabular}

The study is limited to the thirty SSA countries (Note 2) that reported inward remittances receipts for the period2002 and 2011. Remittance flows isrestricted to inter-household unilateral and unrequited transfer of cash earnings, meaning that such transfer is void of any form of quid pro quo terms, across national boundaries only. The implication is that remittances in forms of material transfers by migrant workers to their home countries, compensation of employees, or unrequited inter-household cash transfers within each economy under investigation, are not covered in this study. It is important to clarify here that the study is restricted to the macroeconomic impact of remittances on the receiving economies and not on their microeconomic impact.

\subsection{Model Estimation Technique}

There are two major and important complications arising from efforts to estimate the dynamic panel data regression model referred to in equation (3) using macroeconomic panel data: first, the presence of endogenous and/or predetermined covariates, and second, the small time-series and cross-sectional dimensions of the typical panel data set. The dynamic panel data regression model is in fact further characterized by some sources of persistence over time. There is the problem of autocorrelation which is due to the presence of a lagged dependent variable among the regressors and the other is the problem of heteroskedasticity.

Working within the context of remittance flows, current country remittance realizations will affect future trade performance via its effects on real exchange rate and this may, in turn, affect future country remittance realizations. Thus, giving rise to what may be termed as "dynamic endogeneity". The argument here centers on the fact that cross-sectional variation in observed country economic structures is driven by both unobservable heterogeneity and the country's history. As such, any attempt to explain the role of remittance flows or its effect on trade performance of selected countries that does not recognize these sources of endogeneity may be biased.

The problem of endogeneity that is often associated with the use of panel data analysis are thus resolved in this study by the choice of the System Generalized Method of Moments (GMM) Estimator to estimate the relation between remittance flows and external trade balance. This methodology not only eliminates any bias that may arise from ignoring dynamic endogeneity, but also provides theoretically based and powerful instruments that accounts for simultaneity while eliminating any unobservable heterogeneity. Dynamic panel estimation is most useful in situations where some unobservable factor affects both the dependent variable and the explanatory variables, and some explanatory variables are strongly related to past values of the dependent variable. This is likely to be the case in regressions of remittance flows on external trade balance. This is because remittance flows tend to exert a strong, immediate and persistent effect on trade performance.

In the presence of heteroskedasticity and serial correlation, the two-step System-GMM uses a consistent estimate of the weighting matrix, taking the residuals from the one-step estimate (Davidson and MacKinnon, 2004). Bun and Windmeijer (2009) emphasized that the good performance of the system GMM estimator relative to the difference GMM estimator in terms of finite sample bias and root mean square error, has made it the estimator of choice in many applied panel data settings. In multivariate dynamic panel models, the SystemGMM estimator is also shown to perform better than the Differenced-GMM when series are persistent and there is a dramatic reduction in the finite sample bias due to the exploitation of additional moment conditions (Blundell et al. 2000).

Bond et al. (2001) provide a useful insight in the GMM estimation of dynamic panel data models, arguing that the pooled ordinary least square (OLS) and the least squares dummy variable (LSDV) estimators should be considered respectively as the upper and lower bound. Variations outside these boundaries may therefore be 
considered as a sign that the estimates are biased probably owing to a weak instrument problem. Thus, if this is the case, the use of System-GMM is highly recommended and its estimates should lie between OLS and LSDV.

In view of the obvious strengths of the Blundell and Bond (1998), extended version of the GMM estimator, (also known as system GMM estimator) in overcoming complications that may arise from efforts to estimate the usual linear dynamic panel data models, this estimator was considered appropriate and applied to estimate the specified model for this study.

\section{Empirical Results and Discussions}

Summary of the dynamic panel data model estimation results for equation (3) are presented in Table 2 . The system GMM estimator is categorized into the one-step and two-step options, these are reported in columns 2 and 3 respectively. The OLS and the LSDV results are reported in columns 1 and 4 respectively. Apart from providing some additional robustness check, the results in columns 1 and 4 will also provide a guide based on the position of Bond et al. (2001) that suggest the pooled OLS and the LSDV estimators should be considered respectively as the upper and lower bound for the system GMM coefficients. With this guide in place, it will be easy to tell when each coefficient estimate is either downward or upward biased.

All estimates in columns 2 and 3 are robust to heteroskedasticity or autocorrelation. The related endogenous and predetermined variables on the right hand side of this specification include the REER, WR and lagged ETB respectively. To control for endogeneity of these variables that appear as regressors, internal instruments are utilized; and these include the lagged levels of the standard differenced equation (equation 4) and lagged differences of the levels equation (equation iii). Correlation coefficients (Note 1) between residuals from the base regression and independent variables were computed as an additional check of potential endogeneity problems. An investigation of these coefficients of correlations suggests that none of the independent variables is highly correlated with predicted residuals.

Table 2. Estimated empirical results

\begin{tabular}{|c|c|c|c|c|}
\hline \multicolumn{5}{|c|}{ Dependent Variable: ETB } \\
\hline & Pooled OLS & SYSTEM-GMM & & LSDV \\
\hline Instrument Weight & & $\begin{array}{l}\text { One-Step } \\
\text { collapsed }\end{array}$ & $\begin{array}{l}\text { Two-Step } \\
\text { collapsed }\end{array}$ & \\
\hline Regressors & (1) & $(2)$ & (3) & (4) \\
\hline $\operatorname{ETB}(-1)$ & $\begin{array}{l}0.978^{*} \\
(47.38)\end{array}$ & $\begin{array}{l}0.860^{*} \\
(11.27)\end{array}$ & $\begin{array}{l}0.879 * \\
(14.55)\end{array}$ & $\begin{array}{l}0.455^{*} \\
(5.97)\end{array}$ \\
\hline WR & $\begin{array}{l}-1.42 \mathrm{e}-10 \\
(-0.75)\end{array}$ & $\begin{array}{l}-9.81 e-11 \\
(-0.35)\end{array}$ & $\begin{array}{l}-1.88 \mathrm{e}-10 \\
(-0.72)\end{array}$ & $\begin{array}{l}-4.88 \mathrm{e}-10 \\
(-1.47)\end{array}$ \\
\hline REER & $\begin{array}{l}0.0174 \\
(1.27)\end{array}$ & $\begin{array}{l}0.0578 * * * \\
(1.82)\end{array}$ & $\begin{array}{l}0.0626 * * * \\
(1.99)\end{array}$ & $\begin{array}{l}0.0198 \\
(0.40)\end{array}$ \\
\hline GDPgr & $\begin{array}{l}0.200 * * * \\
(1.76)\end{array}$ & $\begin{array}{l}0.271 * * * \\
(1.95)\end{array}$ & $\begin{array}{l}0.267^{*} \\
(3.48)\end{array}$ & $\begin{array}{l}0.108 \\
(0.86)\end{array}$ \\
\hline INF & $\begin{array}{l}-0.0607 \\
(-1.21)\end{array}$ & $\begin{array}{l}-0.0580 \\
(-1.09)\end{array}$ & $\begin{array}{l}-0.0366 \\
(-0.85)\end{array}$ & $\begin{array}{l}-0.0658 \\
(-1.22)\end{array}$ \\
\hline OPEN & $\begin{array}{l}0.857 \\
(0.43)\end{array}$ & $\begin{array}{l}5.813 \\
(1.24)\end{array}$ & $\begin{array}{l}4.219 * * * \\
(1.77)\end{array}$ & $\begin{array}{l}3.940 \\
(0.65)\end{array}$ \\
\hline Constant & $\begin{array}{l}-3.073 * * * \\
(-1.70)\end{array}$ & $\begin{array}{l}-10.19^{*} \\
(-3.03)\end{array}$ & $\begin{array}{l}-10.12 * * \\
(-2.64)\end{array}$ & $\begin{array}{l}20.61 * * \\
(2.15)\end{array}$ \\
\hline Time Dummy & No & Yes & Yes & Yes \\
\hline Group Dummy & No & No & No & Yes \\
\hline Observations & 270 & 270 & 270 & 270 \\
\hline No. of countries & 30 & 30 & 30 & 30 \\
\hline Instrument count & - & 27 & 27 & - \\
\hline F-stat (Wald $\chi^{2}$ ) & - & 42.79 & 65.55 & - \\
\hline F-stat (p-value) & {$[0.0000]$} & {$[0.0000]$} & {$[0.0000]$} & - \\
\hline $\operatorname{AR}(2)$ & - & {$[0.360]$} & {$[0.437]$} & - \\
\hline $\operatorname{AR}(3)$ & - & {$[0.477]$} & {$[0.466]$} & - \\
\hline Sargan Test (OIR) & - & {$[0.504]$} & {$[0.368]$} & - \\
\hline Hansen Test (OIR) & - & {$[0.729]$} & {$[0.810]$} & - \\
\hline
\end{tabular}

Notes: Robust standard errors are with Windmeijer (2005) finite-sample correction for the two-step covariance matrix.

$\mathrm{t}$ statistics are reported in curly brackets below each coefficient estimate. P-values are reported in square brackets. $*$ indicates significant at 1 percent level. $* *$ indicates significant at 5 percent level.*** indicates significant at 10 percent level 
Some specification tests are examined as a starting point to determine the reliability of coefficient estimates reported in Table 2. The working assumption here is that the idiosyncratic errors $\left(v_{i t}\right)$ in the system GMM estimators are serially uncorrelated for consistent estimations. The assumption that the full disturbance $\left(\varepsilon_{i t}\right)$ is autocorrelated because it contains fixed effects is also made hence; the system GMM estimator is the most appropriate tool to eliminate this potential source of trouble. The Arellano-Bond tests for autocorrelation are reported as $\mathrm{AR}(2)$ and $\mathrm{AR}(3)$ in the lower portion of table 2.The p-values are greater than 0.05 in the one-step and two-step system GMM estimates their values indicate that there is no evidence of serial correlation at the five percent level of significance. Given these results, the estimates can be regarded as consistent and the instruments are valid.

The test of over-identifying restrictions of whether the instruments, as a group, appear exogenous is implemented by the Sargan and Hansen J tests. Here the Hansen J statistic, which is the minimized value of the two-step system GMM criterion function, and is robust to autocorrelation, is of tremendous importance. Only the respective p-values are reported for this test results in the lower part of Table 2. Of course, the null hypothesis that the population moment condition is valid is not rejected if $p>0.05$.In columns 2 and 3 , the summary statistics indicate that the system dynamic panel model of the selected 30 SSA countries has 27 instruments and 16 parameters in both the one-step and two-step system GMM options. This represents a total of 11 over-identifying restriction in each case. Thus, the Hansen-J statistic does not reject the Over-Identifying Restrictions (OIR) hence, the instrument set can be considered valid. The F-statistic which measures the overall significance of all regressors in the estimated model is satisfactorily significant at the one percent level. This is indicative of the fact that all the exogenous variables, in each estimated result, jointly explained significantly, the systematic variations in external trade balance across the sampled SSA countries over the study period.

A look at the control variables reveals that many of the coefficient estimates are satisfactorily consistent with theoretical expectations. The Blundell-Bond robust estimates of lagged external trade balance are positively signed. As can be seen in columns 2 and 3 of Table 2, past realizations of external trade balance positively impact on its contemporaneous levels. These external trade balance dynamics are significant at the 1 percent level in these specifications. In specific terms, a 100 percent increase in external trade balance dynamics will explain about 87.9 percent of the increase in the contemporaneous realizations of external trade balance within the sampled SSA countries. This of course is when the two-step collapsed instruments option is considered. External trade balance dynamics suggest here that external trade balance itself has a way of feeding on its past realizations within the study group.

Surprisingly, the workers' remittance variable is negatively signed and statistically insignificant in both the one-step and two-step system GMM robust estimates. This clearly suggests that although workers' remittance flows to SSA exhibit some potential to depress external trade balance across countries in the sample group for this study, this tendency does not constitute a source of worry for now as it is statistically insignificant.A possible explanation for this observed relationship may be found in the trade patterns of most SSA countries. Many of these economies are characterized by high export concentration index owing to exports of some few primary products. This fact often severely limits SSA capacity to diversify and expand exports in response to changing demand conditions in the foreign trade sector. Imports by SSA economies on the other hand, comprise mainly processed or manufactured goods and high-tech services. A sustained significant increase in remittances receipts by the SSA economies will most likely depress the trade balance of the regional economies on account of consumption pattern that frequently reveals preferences for imported goods and services.

Real effective exchange rate (REER) variable is positively signed and is statistically significant at the 10 percent level when the one-step and two-step system GMM are considered. In more definitive terms, a 100 percent increase in REER produces about 6.26 percent contemporaneous increase in external trade balance across the selected economies. Given this finding, it can be remarked here that real exchange rate depreciation in the selected SSA economies helps improve external trade balance across these economies. This is both expected and healthy for these SSA economies.

Interestingly, growth rate of GDP (GDPgr) is also found to be highly statistically significant at the one percent level and positively related to external trade balance. Contemporaneously, a 100 percent increase in GDPgr leads to about 26.7 percent improvement in external trade balance of the selected economies. This agrees with theoretical expectation and is indicative of export oriented growth economies across the selected SSA economies. Trade openness (OPEN) variable is also positively signed and statistically significant at the ten percent level. This result suggests that the greater the degree of trade openness the greater the external trade balance for these economies. 


\section{Policy Implications of Findings}

Two major policy issues naturally arise from the empirical findings in this study. First, a steady increase in workers' remittances inflow to SSA economies is observed to depress external trade balance over time and across the selected countries within the sub-region. In terms of quantum, this relationship is statistically insignificant; however, appropriate policies are needed to ensure that these financial flows are properly channeled into economically productive uses so as to begin to contribute positively to the external sector of the economies. Second, the positive sign and significant nature of the REER variable in explaining variations in the external trade balance also require some further comments. Increase in this variable indicates a depreciation of the local currency so the positive sign of REER is in line with theoretical expectation. This means that appropriate foreign exchange policies (policies in support of weaker national currencies in order to promote external trade) may be adopted across the SSA countries to maintain a healthy trade balance for the region.

\section{Conclusion}

Given the major findings in this study which clearly highlight the negative but insignificant role of workers' remittances on external trade balance in some selected SSA economies; it is instructive to remark here in conclusion, that policy incentives designed to attract more workers' remittances flow to SSA countries may not be able to help in promoting the goal of maintaining a healthy external trade balance in the selected SSA economies for now. There is therefore the need for adoption of policy options that encourages the economically productive use of remittance inflows into SSA countries. Since remittances are regarded as desirable financial flows in general, the sustenance of these flows and their productive use in the SSA region, demand a central role for governments and monetary authorities in terms of the provision of relevant policy direction.

Every related policy measure therefore should be targeted towards the reorientation of senders and recipients of remittances so as to ensure that these flows are regularly engaged productively. Moreover, it will not be out of place if policy incentives are given a sectoral focus such that remittances are used productively in sectors that are external trade oriented. This will hopefully allow for a sustainably stable external trade balance in the SSA region.

\section{Acknowledgements}

This paper is a part of the first author's PhD Dissertation now revised in article form for journal publication. Professor Donald N. Ike and the second author supervised the PhD Thesis and their contributions in this regard are hereby acknowledged. The management of Covenant University, Nigeria is also acknowledged here for funding the entire PhD programme under the staff development scholarship scheme.

\section{References}

Acosta, P. A., Lartey, K. K., \& Mandelman, F. S. (2009). Remittances and Dutch Disease. Journal of International Economics, 79, 102-116. http://dx.doi.org/10.1016/j.jinteco.2009.06.007

Adams, R., \& Page, J. (2003). International Migration, Remittances, and Poverty in Developing Countries. World Bank Policy Research Working Paper 3179, Washington D. C. World Bank.

Amuedo-Dorantes, C., \& Pozo, S. (2004). Workers' Remittances and the Real Exchange Rate: A Paradox of Gifts. World Development, 32(8), 1407-1417. http://dx.doi.org/10.1016/j.worlddev.2004.02.004

Blundell, R. Bond, S., \& Windmeijer, F. (2000). Estimation in Dynamic Panel Data Models: Improving on the Performance of the Standard GMM Estimator. Institute for Fiscal Studies. IFS Working Papers W00/12

Blundell, R., \& Bond, S. (1998). Initial Conditions and Moment Restrictions in Dynamic Panel Data Models. Journal of Econometrics, 87, 11-143. http://dx.doi.org/10.1016/S0304-4076(98)00009-8

Bond, S., Hoeffler, A., \& Temple, J. (2001). GMM Estimation of Empirical Growth Models. Economics Group, Nuffield College, University of Oxford. Economics Papers, 2001-W21.

Bouhga-Hagbe, J. (2004). A Theory of Workers' Remittances with an Application to Morocco. IMF Working Paper 04/194, Washington D. C., International Monetary Fund.

Bourdet, Y., \& Falck, H. (2006). Emigrants' Remittances and Dutch Disease in Cape Verde. International Economic Journal, forthcoming. http://dx.doi.org/10.1080/10168730600879323

Brown, P., \& Richard, C. (1994). Migrants' Remittances, Savings and Investment in the South Pacific. International Labor Review, 133(3), 357-67.

Bun, M., \& Windmeijer, F. (2009). The Weak Instrument Problem of the System GMM Estimator in Dynamic Panel Data Models. Tinbergen Institute Discussion Paper, TI 2009-086/4. 
Chami, R. A., Fullenkamp, C., \& Jahjah, S. (2003). Are Immigrant Remittances Flows a Source of Capital for Development? IMF Working Paper 03/189. Washington D. C., International Monetary Fund.

Chami, R. A., Barajas, T. C., Fullenkamp, C., Gapen, M., \& Montiel, P. (2008). Macroeconomic Consequences of Remittances. Washington DC, International Monetary Fund, IMF Occasional Paper 259.OCCA.

Davidson, R., \& Mackinnon, G. J. (2004). Econometric Theory and Methods. New York: Oxford University Press.

Lartey, E. K. K., Mandelman, F. S., \& Acosta, P. A. (2010). Remittances, Exchange Rate Regimes and the Dutch Disease: A Panel Data Analysis. Washington, D. C., World Bank.

Lopez, H., Molina, L., \& Bussolo, M. (2007). Remittances and the real exchange rate. World Bank Policy Research Working Paper 4213. Washington, D.C. World Bank

López, J. H., Molina, L., \& Bussolo, M. (2008). Remittances, the Real Exchange Rate, and the Dutch Disease Phenomenon. In Pablo F. \& J. H. López (Eds.), Remittances and Development Lessons from Latin America. Washington D. C. World Bank.

McCormick, B., \& Wahba, J. (2000). Overseas Employment and Remittances to a Dual Econ-omy. Economic Journal, 110, 509-534. http://dx.doi.org/10.1111/1468-0297.00535

Obstfeld, M., \& Rogoff, K. (1996). Foundations of International Macroeconomics. Cambridge, M A: MIT Press.

Olayiwola, W. K., Oyinloye, O., \& Akinrinola, L. (2008). An Empirical Assessment of Old-Age Support in SSA- Evidence from Ghana. Final Report Submitted to African Economic Research Consortium (AERC), Nairobi Kenya.

Rajan, R., \& Subramanian, A. (2005). What Undermines Aid's Impact on Growth? IMF Working Paper 05/126, Washington D. C., International Monetary Fund.

Rodrik, D. (2008). The Real Exchange Rate and Economic Growth. Brookings Papers on Eco-nomic Activity, 2, 365-412.

Roodman, D. (2009). How to do xtabond2: An introduction to difference and system GMM in Stata. Stata Journal, 9(1), 86-136.

Windmeijer, A. F. (2005). Finite Sample Correction for the variance of Linear Efficient Two-Step GMM Estimators. Journal of Econometrics, 126(1), 25-51. http://dx.doi.org/10.1016/j.jeconom.2004.02.005

World Bank. (2006). World Development Indicators. Washington, D. C. World Bank. Retrieved from http://siteresources.worldbank.org/INTSTATINAFR/Resources/ADI_2006_text.pdf (accessed April 17, 2010)

\section{Notes}

Note 1. Details of these results are not reported here but can be made available on request.

Note 2. These countries are: Benin, Botswana,Burkina Faso, Cameroon, Cape Verde, Congo, Côte d'Ivoire, Ethiopia, Gabon, Gambia, Ghana, Guinea, Guinea-Bissau, Kenya, Lesotho, Madagascar, Malawi, Mali,Mozambique, Namibia, Niger, Nigeria, Rwanda, Senegal, Seychelles, Sierra Leone, South Africa, Swaziland, Tanzania, andTogo. 